\title{
Analysis of a Surface Collection from the L. A. Hale (41TT12) Mound Site, Titus County, Texas
}

Timothy K. Perttula

Heritage Research Center, Stephen F. Austin State University

Follow this and additional works at: https://scholarworks.sfasu.edu/ita

Part of the American Material Culture Commons, Archaeological Anthropology Commons, Environmental Studies Commons, Other American Studies Commons, Other Arts and Humanities Commons, Other History of Art, Architecture, and Archaeology Commons, and the United States History Commons

Tell us how this article helped you.

This Article is brought to you for free and open access by the Center for Regional Heritage Research at SFA ScholarWorks. It has been accepted for inclusion in Index of Texas Archaeology: Open Access Gray Literature from the Lone Star State by an authorized editor of SFA ScholarWorks. For more information, please contact cdsscholarworks@sfasu.edu. 


\section{Analysis of a Surface Collection from the L. A. Hale (41TT12) Mound Site, Titus County, Texas}

\section{Creative Commons License}

\section{(c) (1) \&}

This work is licensed under a Creative Commons Attribution-NonCommercial 4.0 International License 


\section{Analysis of a Surface Collection from the L. A. Hale (41TT12) Mound Site, Titus County, Texas}

\section{Timothy K. Perttula}

\section{INTRODUCTION}

This article, and the three that follow in this volume, are summaries of artifact surface collections obtained by Robert L. Turner, Jr. at four sites in the Big Cypress Creek basin in the Post Oak Savanna and Pineywoods of Northeast Texas (Figure 1). The first surface collection is from the L. A. Hale Mound site (41TT12) on Blundell Creek, a southward-draining tributary to Big Cypress Creek.

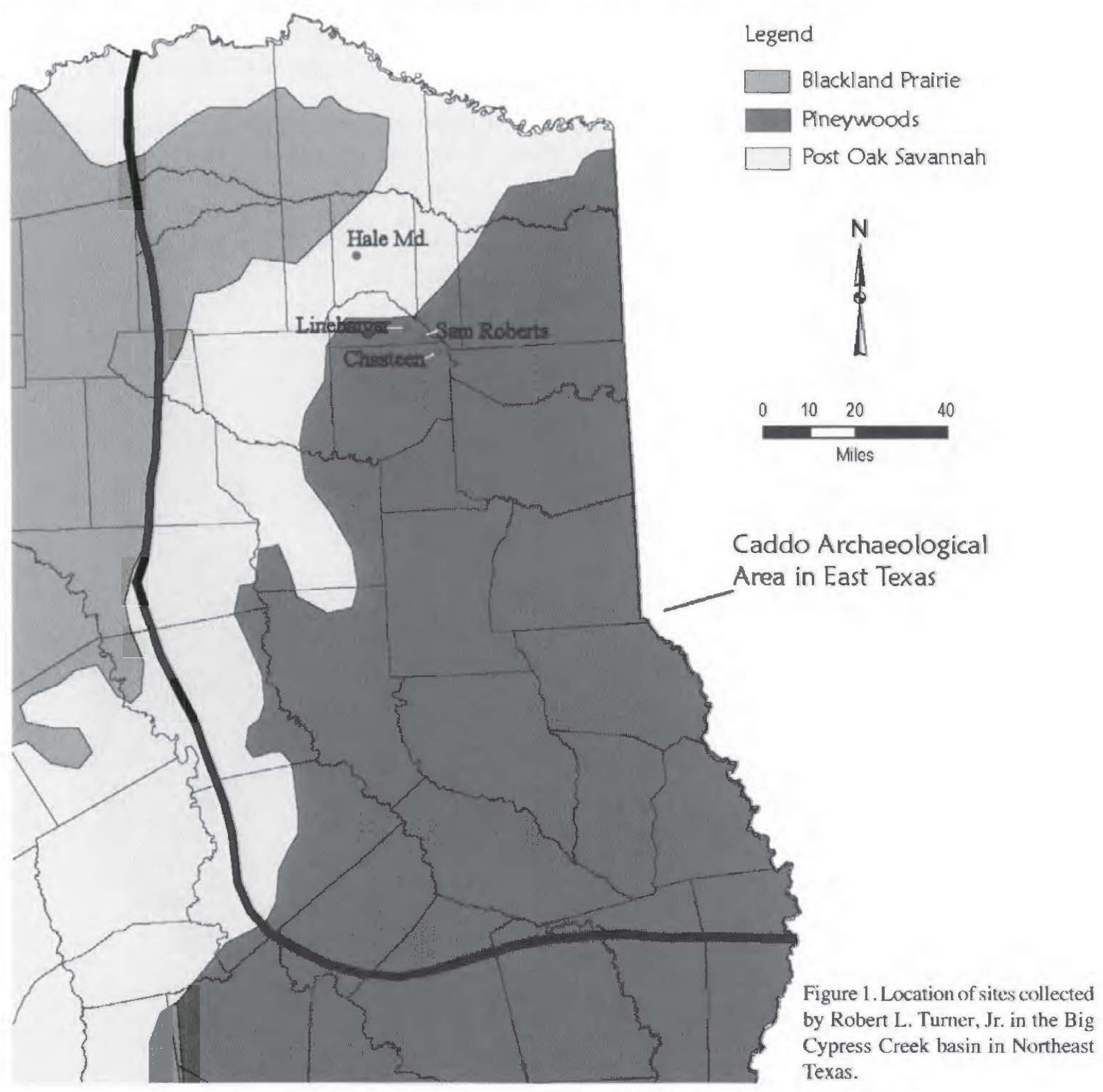


According to Thurmond (1990:187), the principal component at the L. A. Hale Mound site is an Early Caddo (ca. A.D. 900-1200) mound center with extensive midden deposits. There are six mounds at the site, two large platform mounds (Mounds 1 and 2) and four low mounds that cover occupational deposits and burned house structures. There are also four large midden areas adjacent to the earthen mounds as well as at least one borrow pit (Thurmond 1990:Figure 24). In addition to the Early Caddo component, Thurmond (1990:187) has recognized Late Paleoindian, Early Archaic, Middle Archaic, Late Caddo Titus phase, and an early historic Anglo-American occupation from material culture remains recovered in excavations conducted at the site in 1934 by A. T. Jackson (1934) at The University of Texas and a 1980 surface collection by Susan Lisk of The University of Texas at Austin. Turner's collection adds additional information on the occupational history of the site. The exact location of the surface collection area at the site is not known.

\section{LITHIC ARTIFACTS}

The lithic artifacts from the L. A. Hale Mound site in the Turner collection include fire-cracked rock $(n=1$, quartzite), lithic debris ( $n=1$, non-local dark gray chert), one flake tool (bilateral, non-local gray chert), three biface fragments (quartzite, $n=2$, and dark gray chert, $n=1$ ), a dart point, and a large broken ferruginous sandstone biface. The dart point is a complete Woodland period Gary, var. Camden specimen made from a heat-treated quartzite (Figure 2a). It is $6.7 \mathrm{~mm}$ thick, and has a narrow stem width $(11.5 \mathrm{~mm})$.

The ferruginous sandstone biface fragment is a thick percussion-chipped piece with cortex remnants on one chipped surface (see Figure $2 b$ ). The biface was broken in manufacture by a lateral fracture.

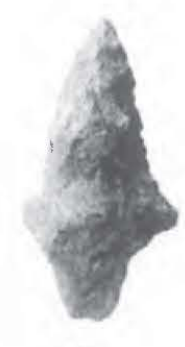

a
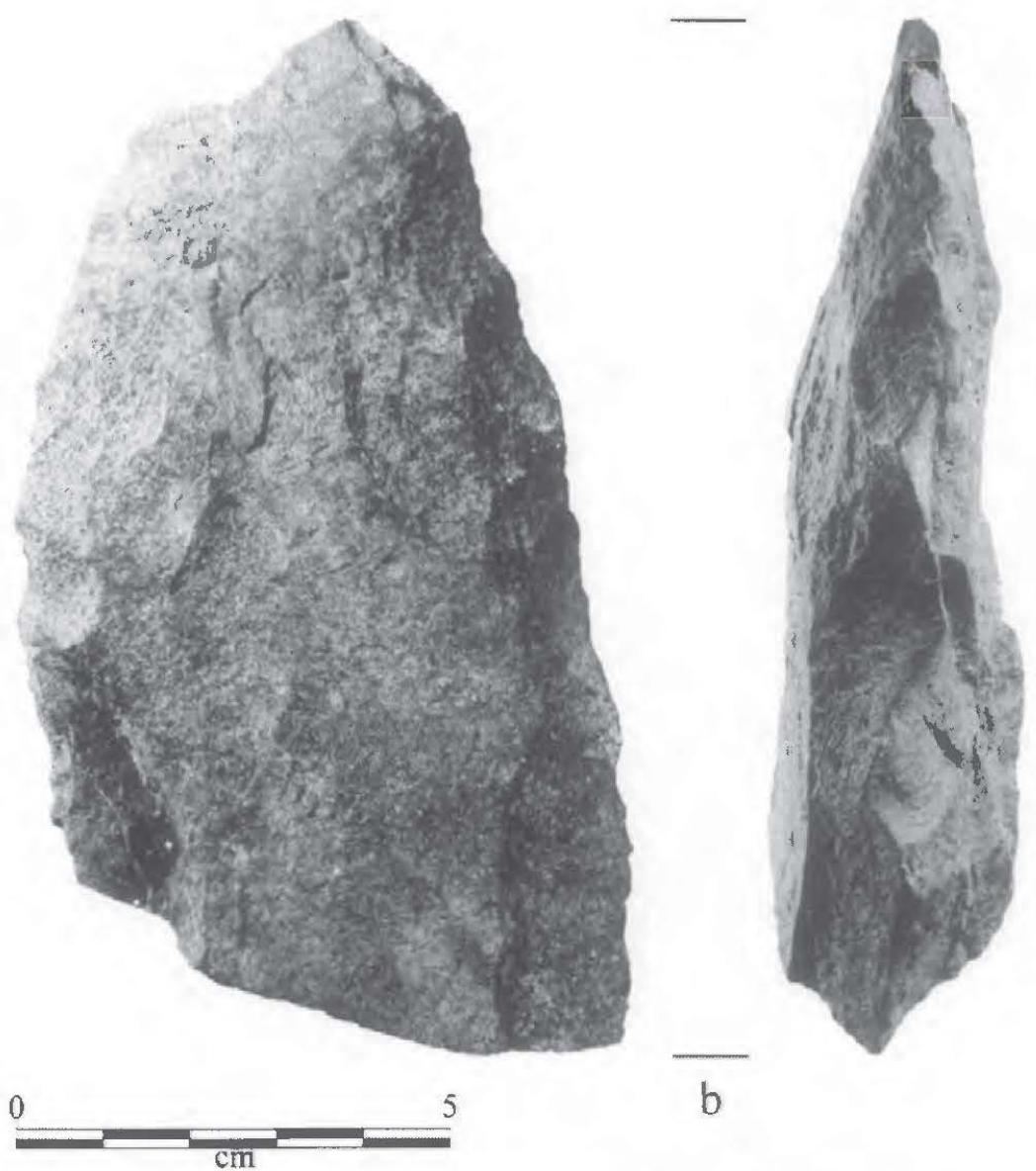

Figure 2. Lithic artifacts from the L. A. Hale Mound site: a, Gary point; b, ferruginous sandstone biface. 


\section{CERAMIC ARTIFACTS}

The Turner collection from the L. A. Hale Mound site has 58 sherds, 43 plain body and base sherds, and 15 decorated rim and body sherds. The plain/decorated sherd ratio is 2.87 . The plain sherds are from relatively thick vessels: $8-9 \mathrm{~mm}$ for body sherds and $11-15 \mathrm{~mm}$ for base sherds. Approximately $64 \%$ of the sherds are from grog-tempered vessels, and the remaining $36 \%$ are from bone-tempered vessels.
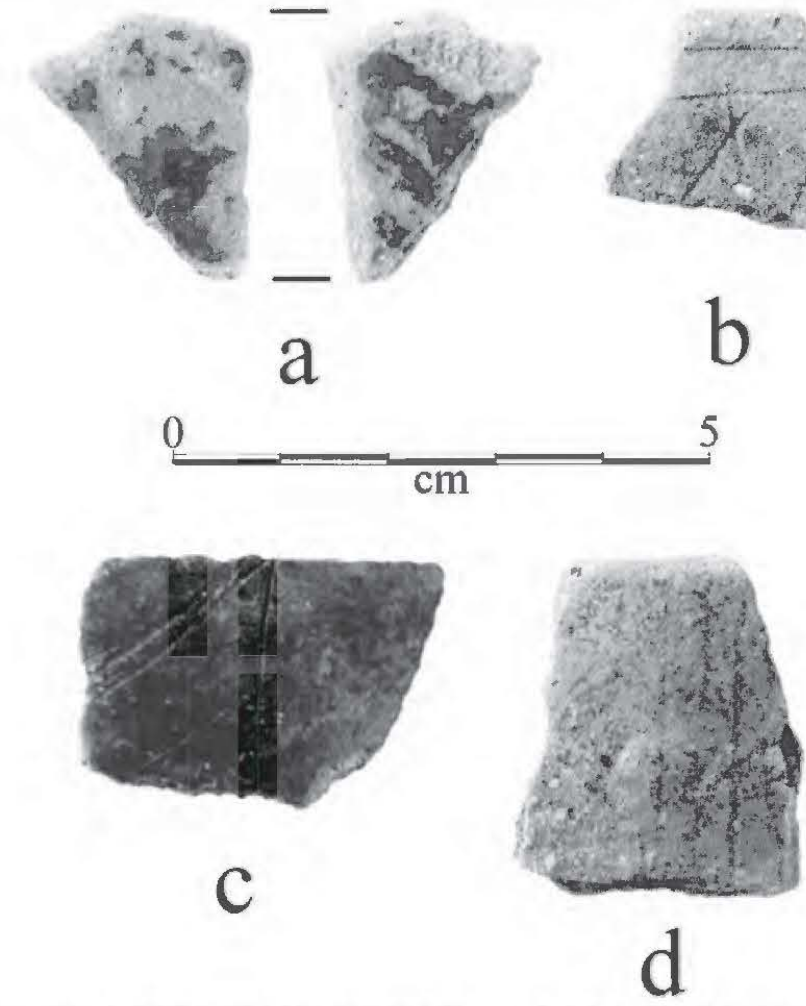

Figure 3. Fine ware sherds from the L. A. Hale Mound site: a, interiorexterior red-slipped body sherd; $\mathbf{b}$, horizontal and diagonal engraved rim sherd; c, diagonal engraved body sherd; d, Holly Fine Engraved rim sherd.
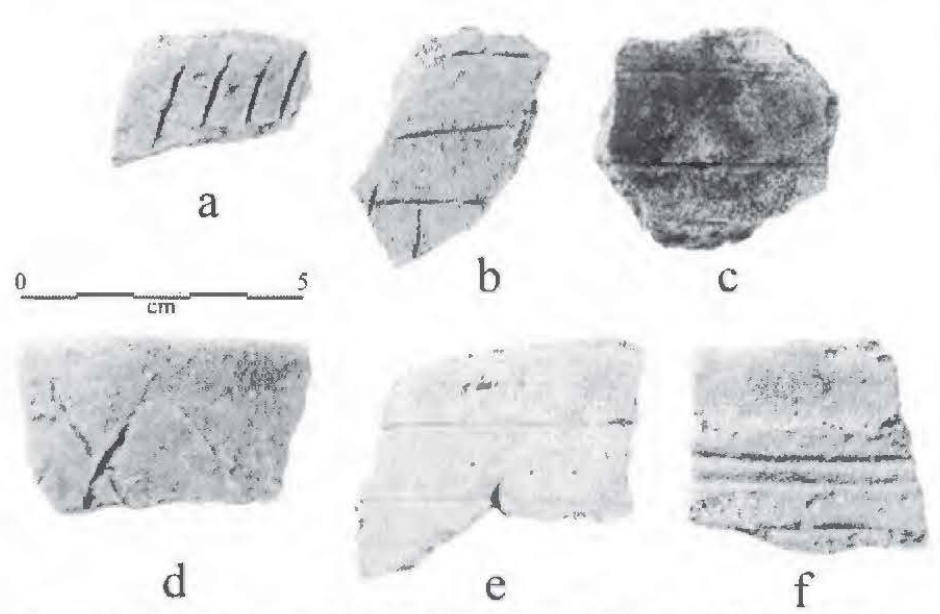

Figure 4. Incised rim and body sherds from the L. A. Hale Mound site: a, parallel incised body sherd; b, opposed incised body sherd; $c$, widelyspaced horizontal incised body sherd; $d$, cross-hatched and diagonal incised rim sherd; e, widely-spaced parallel incised body sherd; f, possible Coles Creek Incised body sherd.
The 15 decorated sherds include four fine ware sherds, one from a bowl or carinated bowl with a red slip on both vessel surfaces (Figure 3a) and three rim and body sherds from carinated bowls (Figure 3b-d). These include a Holly Fine Engraved rim (direct profile and a rounded lip) with an excised triangle (Figure $3 d$ ), another rim (direct profile and a rounded lip) with horizontal, cross-hatched, and diagonal lines (Figure 3b), and a body sherd with diagonal engraved lines (Figure $3 \mathrm{c}$ ).

The utility ware sherds $(\mathrm{n}=11)$ are primarily from jars with incised lines on the rim (Figure 4a-f). The other utility ware sherd is a bone-tempered rim sherd (direct profile and a rounded lip) with rows of tool punctations (Figure 5).

The one incised rim sherd (direct profile and a rounded lip) has cross-hatched and diagonal incised lines (see Figure 4d). Body sherds have widely-spaced parallel incised lines $(n=4)$ (see Figure $4 a, e$ ), horizontal incised lines on a collared rim, possibly from a Coles Creek Incised, var. Chase barrel-shaped jar (see Figure 4f), sherds with opposed incised lines $(n=3$, see Figure $4 b$ ), and a body sherd with a straight incised line.

\section{MISCELLANEOUS ARTIFACTS}

In addition to ceramic and lithic artifacts, three pieces of daub and a single piece of burned animal bone (unidentified to species) were recovered in the Turner surface collection. 


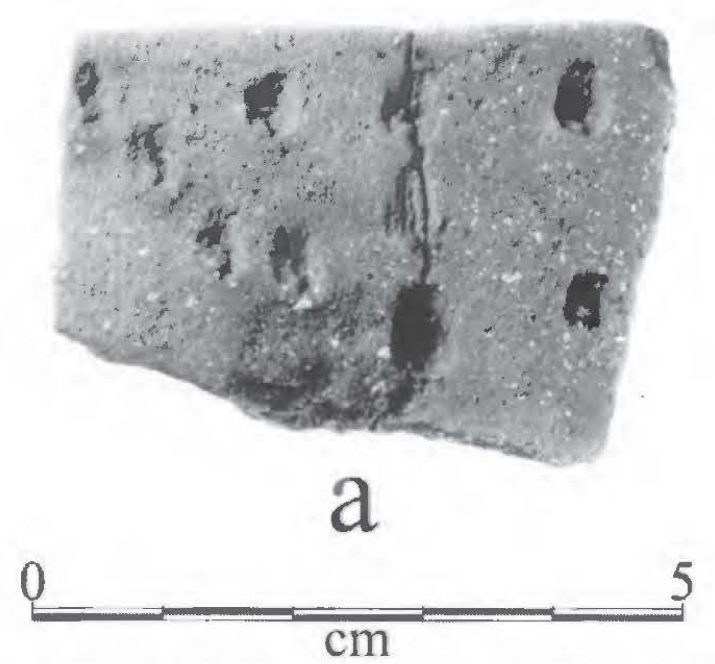

Figure 5. Tool punctated rim sherd from the L. A. Hale Mound site.

\section{CONCLUSIONS}

A small surface collection from the L. A. Hale Mound primarily reflects the fact that the primary component at the site dates from the Early Caddo period (ca. A.D. 900-1200). Diagnostic ceramic sherds from this component include a Holly Fine Engraved rim sherd and a possible Coles Creek Incised, var. Chase body sherd. There are unidentified engraved fine wares from carinated bowls as well as a redslipped bowl or carinated bowl sherd, and incised and tool punctated utility wares. The lithic artifacts include a ca. A.D. 200-700 Gary, var. Camden dart point, indicative of some use of the L.A. Hale Mound site during the Woodland period and a large ferruginous sandstone biface, which may be from a limited Middle or Late Archaic period use.

\section{ACKNOWLEDGMENTS}

I would like to thank Robert L. Tumer, Jr. and Bo Nelson for the opportunity to study the surface collections from the L. A. Hale Mound site, as well as the Linebarger, Chasteen, and Sam Roberts site collections discussed in articles to follow in this volume. Lance Trask prepared the maps and artifact figures for each of the four articles.

\section{REFERENCES CITED}

Jackson, A. T.

1934 Trenching of an Earth Mound, L. A. Hale Farm, Titus County, Texas. MS on file, Texas Archeological Research Laboratory, The University of Texas at Austin.

Thurmond, J. P.

1990 Archeology of the Cypress Creek Drainage Basin, Northeastern Texas and Northwestern Louisiana. Studies in Archeology 5. Texas Archeological Research Laboratory, The University of Texas at Austin. 